\title{
Tumor Protein 63 Isoform 2
}

National Cancer Institute

\section{Source}

National Cancer Institute. Tumor Protein 63 Isoform 2. NCI Thesaurus. Code C128298.

Tumor protein 63 isoform 2 ( $586 \mathrm{aa}, \sim 66 \mathrm{kDa}$ ) is encoded by the human TP63 gene. This protein plays a role in the mediation of both transcription and skin development. 